\title{
Migration and Muslim Identities: Malawians and Senegalese Muslims in Durban, South Africa ${ }^{1}$
}

\section{Shahid Vawda}

\section{Abstract}

This paper is about foreign African Muslims, particularly Malawian and Senegalese Muslim migrants in Durban, South Africa. Modern $21^{\text {st }}$ century migration processes are a global phenomenon deeply embedded in a complex interaction of social, economic and political patterns and processes, often leading to concentrations and enclaves people in large urban centres, such as Durban, along lines of religious, ethnic or national origins. Durban itself is also a major urban area in Southern Africa with a significant Muslim population and a centre of Islamic influence reaching out across the sub-continent, and may serve as a point of attraction for African Muslim migrants. Religious identity is an important factor that is imbricated in Malawian and Senegalese Muslims attempts to search for new solutions to their problems of adaptation, integration and assimilation into a new place. A key issue addressed in this paper is whether their identities, particularly religious, ethnic and national identities, rather than the normative values, provide a set of resources to accommodate themselves and pursue their aims of being gainfully employed as entrepreneurs and workers in a different country. De Certeau's conceptual distinction between strategy and tactics is used as a framework to evaluate the way in which Malawian and Senegalese migrants use religion and associated values towards making a life for themselves in Durban.

Keywords: Durban, identities, Malawian, migration, Muslim, racism, Senegalese, strategy, tactics, xenophobia

${ }^{1}$ Presentation at the 2017 ASRSA Congress, held at the University of Cape Town, Cape Town, July 2017. Please note that a shorter version of this paper, with less bibliographical and ethnographic details will be published in an upcoming issue of the Annual Review of Islam in Africa (ARIA) - Editors. 


\section{Introduction}

Religion has in many ways provided a moral or normative basis for social interaction and solidarity, rather than seen as instrumental in the making and perhaps unmaking of social life. The question that I address in this paper is how do Muslim Senegalese and Malawian migrants articulate the specific use of religion as a way of making a living in Durban and in the process realize other objectives they might have. In the context of increasing foreign migration from the rest of Africa to South Africa, in particular to its cities, the issue of migrants being employed and accommodated as well as finding ways to integrate or assimilate themselves has been foremost in many analysis of transnational migration to South Africa (for example: Rogerson 1997; Reitzes 1998; Vawda 1994; and 2000; Morris 2001; Bouillon 2001; Danso \& McDonald 2001; Crush \& Williams 2002; Tlou 2007; Polzer 2008; Buyer 2008; Landau 2012; Jinnah 2015). Although there are specifics of the debate in South Africa, entangled as it is with post-apartheid development issues, citizenship and xenophobia, the presence of foreign migrants and their cultural contexts is also part of a much larger global debate on religion and migration and the prospects of migrants integration and assimilation into the society of their destination, whether it is Europe, Turkey, the Arabian peninsula, the USA, Canada, Hong Kong, Macao or Australia.

Integration or assimilation into South African society is not a simple process: it is not without its power plays between, what may be called the struggle between the 'powerful' such as the state and its agencies, and the 'poor' particularly those that try to making a living in the hidden worlds of undocumented migrants, or as refugees and exiles. In this paper I wish to explore a particular aspect of that transition to making a new life in a country that is itself deeply embroiled in its own difficult transformation attempting to live up to the very humane sentiments of its constitution. The particular aspect that I wish to explore is how do those migrants who are Muslim, find ways in which Islam (or being Muslim), a foreign national and a migrant counts as useful or has some cachet, in making a new life primarily focused on livelihood and accommodation strategies, while simultaneously being transnational migrants in a set of historical contingencies that are fraught with multiple difficulties, not least of which is sufficient remittances to their homes in their countries of origin. 


\section{Islamic Practices in South Africa}

Historically Islam and Muslim practices in South Africa have always inveighed against oppression, inequality and injustice (see Essack 1988; 1992; Tayoob 1995; 1999a; and 1999b; Germain 2007; Bangstad 2007; Mathee 2008). Yet Islam's debate with inequality and injustice shifts significantly in the postapartheid period. Given the constitutional space to practice religion unhindered, many local Muslims in South Africa began to focus on values of piety and morality, rather than continue to engage in the larger public debates about recognition of cultural differences and the relevance of Islam in times of continued inequality, nation building, reconciliation, reconstruction and development ${ }^{2}$. The focus on intrinsic normative driven standards of expected behaviour derived from religion, rather than public engagement, represents a shift towards a particular normality of inward looking Islam. The new wave of Muslim migrants since the early 1990s (Bouillon 2001; Crush 2002; Segatti \& Landau 2012) from Africa disrupts this normality. It presents a new phenomenon that taps into debates about new forms discrimination and xenophobia (Hassim et al. 2008; Monson, Landau, Misago \& Polzer 2010; Landau 2012), and implicitly about migration and religion (Hansen, Jeannerat \& Soudouni 2009) that represents the alterity of the foreign 'other' rather than mimesis. While discrimination and xenophobia against the 'foreign other' is vitally important, inflected with minority religion status, it also allows to question the 'use of religion' by migrants as a cultural resource in the migration process, rather than a normative standard to judge behaviour.

As migrants often come from fragile, collapsing or collapsed states and societies, where the issue of the politics of post-colonialism, and ideals of nation building, reconstruction and development is (or was) high on the agenda, or rather its less than spectacular successes often lie at the heart of why they are here and what they do. In particular the question may be posed as to what implications do their practices in their new places of living, have for understanding religion as part of the migrants' situational context in South African and in a world where the valued principles of tolerance and respect for diversity are under threat of xenophobia and racism. The issue is not much the difference between normative or textual representations and actual practices (a

${ }^{2}$ Questions on gender and queer politics are also an important feature of Islam and post-apartheid politics. This is an important area of research and public engagement. However, this is not the focus of this paper. 
common enough analytical practice in the social sciences) but what do migrants make of these representations in their own practices. How do they perform their presence with the cultural tools at their disposal to shape the way in which they are received and set their own agendas and realize (or fail) their itineraries within a competing set of agendas? These are issues that will be discussed through the use of two case studies of African Muslim migrants (though not exclusively), from Senegal and Malawi framed through the analytical lens of de Certeau's concepts of strategy and tactics. Other frameworks involving notions of power could also be used to analyse the relationships of foreign migrants to their hosts, such as dependency theory (see Vawda 1994; 2000), or Foucauldian inspired studies of migrants as the disciplined 'other' (Fassin 2001) and migration and governmental power (Fassin 2011; Walters 2015), or a rights based approach related to questions of citizenship (see for example Dagnino 1994; Manby 1997; Peberdy \& Crush 1998; Crush 1998; Klaaren 1999; Vawda 2000; and 2008; Albertyn 2008; Misigo 2009; Landau 2014). However, in this paper I want to understand the specific use of the content of religious, as well as ethnic and national identities in so far as they are imbricated in the issues I address, to inform decisions that have a direct bearing on everyday practices of migrants, in particular their ability to articulate and carve out a space to provide for themselves in Durban through their creativity and manipulations of what exists and confronts them as a multitude of institutions and power structures. To this end I use de Certeau's distinction between strategy and tactics to explore how Muslim migrants not only 'make do' within an already instituted or 'established forces and representations' (de Certeau 1984: 18), but produce stratagems and tactical manipulations that re-fashions and overcomes the constraints of the rules, procedures and administrative opacity.

The emphasis on the practices of the everyday, places the burden of explaining African realities from the busy-ness of their lives. As noted by Simone (2004) that African lives are completely occupied with work, in a range of senses, from physical work and a preoccupation with the constant need for money as the single most important thing in their lives (Stiamen \& Guyer 1995; Guyer 2004), to daily configurations and ruminations of how to provide for themselves. There is a growing literature that takes seriously these African practices in an era of large scale economic and political transformation driven by structural adjustments, trade regulation or deregulation, fiscal austerity packages, post-cold war demands for democratization, or of notions of post- 


\section{Shahid Vawda}

colonial state failure or political instability, assuming that we know what is a successful post-colonial state or political stability (Mbembe 1992; 2001). These practices (and discourses) may be conceived as 'making do' or 'bricolage' of everyday 'makeshft' actions for living within an established order (de Certeau 1984: XV), or as coping or survivalist strategies within the historical contingencies that Africans find themselves in.

Taking de Certeau's programmatic statements on the practice of everyday life seriously, he prompts us to think beyond the mere 'fact' of the conditions and coping strategies. However painful, obviously unequal, contradictory and disjunctural the relations between North and South and between local ruling elites and the mass of poor people are he argues that they may not be 'immutable' (1984:16). Indeed, as Makhulu, Buggenhagen and Jackson point out (2010:20) there is a need to understand them as 'new modes of being in the world, new forms of cultural praxis with both material and existential consequences ... (as) a product of collective human praxis'. Makhulu et al. (2010) and Simone (2001; 2004) contemplate these new modes, not so much as the debris of underdevelopment (cf. Frank) or as incomplete modernisation, or varieties or multiple modernities (Von Schimdt 2004), but where this might be considered the most advanced forms of globalization and neo-liberal capitalism (Ferguson 2005; 2006), and the responses of people at the level of the everyday. To take practices as a serious starting point contemplates both being 'trapped in dependency, forced to submit to the facts' of its institutions and structuring of life and simultaneously to 'subvert the fatality of the established order' (de Certeau 1984:16-17).

De Certeau's concept of strategy is a calculation or manipulation of events or people in power relationships within a place. Place is any space defined as its own by the individual, people or group of people concerned to serve as a base from which relations with those exterior to it can be conducted.

I call a strategy the calculation (or manipulation) of power relationships that becomes possible as soon as a subject with will and power (a business, an army, a city, a scientific institution) can be isolated. It postulates a place that can be delimited as its own and serves as the base from which relations with an exteriority composed of targets or threats (customers or competitors, enemies, the country surrounding the city, objectives and objects of research, etc.) can be managed (1984:35-36). 
In the context of this paper both the Malawians and Senegalese defined two very different places within the city of Durban from which they situate themselves, both in terms of where they reside and to provide or construct a livelihood for themselves in relation to range of people with whom they conduct various kinds of relationships, ranging from dealing with state agencies to customers, neighbours and their families back home.

To be noted is that while the places are pre-defined as already existing, such as the central business district, it is the way in which the Malawians and Senegalese think about place and operate in ways that produces the space for the realization of their particular strategic goals and objectives. Tactics on the other hand, de Certeau defines somewhat negatively in the first instance as the absence of place.

By contrast with strategy (whose successive shapes introduce a certain play into this formal schema and whose link with a particular historical configuration of rationality should also be clarified), a tactic is a calculation determined by the absence of a proper locus. No delimitation of an exteriority, then, provides it with the condition necessary for autonomy. The space of the tactic is the space of the other (1984: 36-37).

Tactics are also calculation based, tools that firstly allow for the manipulation of social relationships that they find and have to engage with beyond the dictates and expectations of a place. In short, both strategy and tactics are calculations: while a strategy operates within a defined or articulated space that takes into account its variables, a tactic operates in relation to others, rather than in relation to a place. Buchanan describes tactics as "practices that strategy has not been able to domesticate, they are not in themselves subversive, but ... have symbolic values which is not to be underestimated: they offer proof of the partiality of strategic control and in doing so they hold out the token hope that however bad things get they are not necessarily so. In other words, tactics operates primarily on the plane of belief' (Buchanan 2000:89).

As we shall see, both the Malawians and Senegalese not only engage among themselves but with a range of people, organisations, ideas and 'beliefs', whose reach may well be beyond the specific place of their daily activities. 


\section{The Differentiated Contexts for African Muslim Migrants}

There is no doubt that there is a visible increase in continental African and other migrants and immigrants in South Africa, particularly since the early 1990s. This does not mean that there was no previous African or indeed other migration to South Africa. Under Apartheid the tight control of African continental migration, mainly from Malawi, Botswana, and Mozambique, ensured that their singular major contribution to South Africa was their labour, and hence to the growth of an industrial economy. Under a highly controlled migration system during the segregation and apartheid periods (1924-1986) foreign migrants public presence was hidden away in the single sex mining compounds and hostels, invisible to the South African public. That system of controlled migrations and exploited labour no longer exists (Chirwa 1997). Some of these forced labour migrants may well have been Muslims, but precisely because they were hidden behind mining compounds, their religion and practices have not been visible and examined. The most visible presence of Muslims were those that came to South Africa from the Indian subcontinent and Indonesia as a result of Dutch and British colonial practices in the $17^{\text {th }}$ to $19^{\text {th }}$ centuries. These were mainly Muslim slaves from other Dutch colonies transported to the Cape Colony and later, under British colonial rule, the passage of indentured labourers, traders and various professionals, a portion of which were Muslims, to South Africa. A new wave of Muslim migrants have been arriving in the late $20^{\text {th }}$ and early $21^{\text {st }}$ centuries from different parts of the world, and in particular from Africa.

There are no statistics that are kept on a religious basis to be able to present with any precision what the numbers of foreign Muslim migrants are in South Africa. While some statistics are kept on documented migration to South Africa on country, gender and occupational basis this does not include refugees and asylum seekers. Nor does it include undocumented migrants ${ }^{3}$.

${ }^{3}$ There was a debate on the numbers of illegal or undocumented migrants in South Africa. Some 'researchers' presented grossly inflated figures to indicate that almost of half the current South African population were made of illegal or undocumented migrants. This debate was finally settled when the Human Sciences Research Council stated in 2002 that it was all but impossible to give any precise figures for undocumented migrants. This is not to say there are no undocumented or illegal migrants. 
It would be safe to say that most Muslim migrants, both documented and undocumented, come from countries in Africa where there is a significant, if not a majority, Muslim presence. This would be countries such as Somalia, Sudan, Kenya, Cameroon, Burundi, Tanzania, Malawi, Senegal, Cote d'Ivoire, Nigeria, Ghana, Zimbabwe, Burundi and Rwanda. Muslims also come from Asian countries such as Bangladesh, India, Malaysia, Indonesia, Pakistan and various Middle East countries. A further distinction may also to be made between legal immigrants who come to work with a view to permanent residency in South Africa and migrants who find work in South Africa as a necessity, or as part of a contract of employment for specific periods of time (Reitzes 1997; 1998). Before we analyse the ways in which migrant African Muslim have made their presence felt in South Africa, a brief outline of the contemporary context of migration is necessary.

A number of conditions have been set in motion for these new streams of migration from the rest of Africa to South Africa. The first set of conditions is essentially the push factors in the country or place of origin. Among this first set of push factors is political instability, prompting a stream of refugees. These are mainly from the civil wars and political problems experienced in various parts of Africa, but mainly in the Great Lakes region encompassing the countries of Rwanda, Burundi and the Democratic Republic of Congo, but also from places such as Ethiopia, Somalia, Sudan, Nigeria and Ivory Coast. Unlike other countries, South Africa does not have refugee camps, and so refugees, once they have affirmed their status with the Department of Home Affairs, are left to fend for themselves. They may seek and accept employment or be selfemployed within the confines of the law. Despite their official status they become like migrants - temporary sojourners seeking employment.

The second set of conditions is located in the myriad ways in which African economies have collapsed, either through structural adjustment programmes or through inadequate or corrupt state administration and management, or both, prompting a stream of some people migrating to find new livelihood opportunities. These are economic migrants. Many of these migrants choose to come to South Africa because they have heard or been exposed to the media that portrays it as a powerful economy with plenty of opportunities. For some such migrants, South Africa is their second or third choice of destination after Europe or the United States of America, because of the tightened immigration laws in Europe and restrictive conditions for immigrating to the USA. 
A third set of conditions is that some migrants simply seek to explore what conditions exist in the new South Africa. The miracle of democratic transition and continuing stability exerts a powerful attraction for African adventurers, professionals and entrepreneurs to seek out opportunities ranging from post-secondary school education, investment and employment opportunities in sectors such as universities, professional services, retail and manufacturing to acting as consultants to industry and government. But it should be noted that xenophobia, limited opportunities, the difficulty of restarting their lives are at first a horrible shock. Expectations of plenitude, sympathy and solidarity, if present, as is often the case with refugees and migrants generally, are rapidly removed from their consciousness. Many migrants, rather than return empty handed, stay and exploit whatever opportunities do exist. However, such opportunities exist in highly prescribed and socially conceptualised ways. It is in this context that African Muslim migrants must be understood, in particular the different ways in which Senegalese and Malawian Muslims pursued the necessity of making a living and re-constituting their religious and other identities in a country struggling with its own ethnic and racial past and the reconstruction of itself as a new nation.

A number of observations may be made from this brief account of recent migration patterns. The first is that not all migrants are the same and may also be differentiated by their class, religious affiliations, occupational and national origins, which in large measure bear on their ability to insert themselves into the tough economic conditions that prevail in South Africa's transitional period. For example those from middle and upper class and educated backgrounds, regardless of religious affiliation, find it easier to integrate themselves into the South African economy and society. The second observation to note is that the African countries from which most migrants arrive do not all have Muslim majorities, but many do have significant numbers of Muslims. It would be misleading to assume that all foreign migrants from these countries with Muslim majorities are indeed Muslim. In the context of this paper, reference is often made to African migrants and to migrants especially from Senegal, Somalia or Malawi. In the case of the first two these countries, they have between $95-100 \%$ Muslim population, and thus it is assumed that most migrants from these countries are Muslim. In Malawi 35\% of its 9.5 million people is Muslim assuming a corresponding ratio of Malawian Muslims in South Africa. The third observation is that what constitutes a 
Muslim or Islamic community in South Africa is now highly ambiguous. African Muslims invalidate the foundational myths of apartheid that Islam equates with an eastern religion or Indian religion thus undermining ingrained shibboleth of ethnic and racial stereotypical thinking, posing the question of how Islam is currently articulated and practiced by African migrants.

As a religious category, being Muslim needs to be put in perspective. Membership of the Muslim community - the Umma, i.e. a sense of community united through religion that transcends race, ethnic and national group identities - is a highly contested one world wide. In South Africa it can take many forms of affiliations based on Islamic schools of thought, religious practices and affiliations, ethno-nationality to name but a few. Thus for example, Senegalese Muslims might well disagree with conservative South African Muslims or Malawian Muslims on the status and veneration of their ancestral spiritual leader Sheik Ahmedou Bamba. Differentiation in Islamic religious practices became apparent. Apart from ritual and language practices, other indices of differentiation might be levels of activity, or lack of such activity in Islamic missionary work and welfare organizations, preferences about their distance from organized or institutionalized religion and outward displays of piety and devotion to Islamic practices. Although such issues raise doctrinal disputes among Muslim scholars about who belongs to the Umma, the actors themselves would probably see themselves as Muslims or at the very least think of themselves as Muslims in a cultural sense of belonging to a group (see Brenner 1993; Launay 1992; Soares 2007; McIntosh 2009).

Muslims are also differentiated along lines of race, class, nationality, and gender. These sociological aspects, albeit intertwined with religious precepts and values, are important in the way African Muslim migrants, as suggested above, structure their relations with the local Muslims (i.e. those of Indian or Indonesian descent) and among themselves. But religious affiliations, loyalties and influences are never static and are conditioned by circumstances and situations that individuals and groups find themselves in. In the case of African foreign Muslim migrants, as I shall show later, in highlighting their Muslim identity, though not necessarily their particular religious affiliation, piety, or other characteristics, may be crucial to mobilizing and accessing resources - food, shelter, funds, places of worship, sites to conduct rituals - in order to survive in South Africa.

A final observation is that while xenophobia exists (Worby \& Hassim 2008; Landau 2012), there is a broader issue of the rights and entitlements 


\section{Shahid Vawda}

African migrants inhere into their itineraries, agendas, social and economic interactions and religious practices in the social and public spaces in which these are pursued. In other words how do rights and entitlements become part of the strategic and tactical calculations of Malawian and Senegalese migrants.

\section{Initial Interactions and Survival: Accommodation and Livelihood Strategies of African Migrants}

Continental African migrants do not see themselves as simply one kind of immigrant. Many continental African migrants are here as result of complex intertwining of political, economic and sometimes personal reasons for leaving their countries of origin and fleeing thousands of kilometres to the southern tip of Africa. Thus many Senegalese, Nigerian, and Cameroonian migrants say that they are political asylum seekers because of their oppositional role in politics to the previous regimes in their home country, but also they cannot find work, and were forced to leave their country. Others such Somali, Sudanese, Rwandans state that they are refugees. Asylum seekers may claim to be victims of their political activities, but they also seek refuge from the constraints of a less than robust economy. Others such as the Malawians are forthright in their reasons for coming to South Africa: they come to seek work. Furthermore while a broad distinction can be made between refugees and exiles on the one hand and economic migrants can be made, not all who claim asylum or refugee status act in accordance with that status. Senegalese, Nigerian and Cameroonians are entrepreneurs, traders or professionals, and more often than not their issues are with restrictions related to their ability to ply their trades, and less concerned with accessing resources from welfare and UNHCR agencies. Similarly Somali refugees, although initially dependent on welfare agencies have since created their own forms of self-organization and pursued trading and entrepreneurial activities on the streets and pioneered trading in the townships, often moving into formal trading activities. While these broad generalizations may be made, it is the precise strategies that need to outlined.

Although asylum seekers and refugees are generally grateful to be accepted into the country, it has been a difficult experience for the first few of them to find accommodation and establish a means of livelihood. Given the paucity of State assistance, they have had to rely on a number of strategies to finding accommodation, various means of survival and employment or self- 
employment. The first of these strategies is the identification and seeking the assistance of people from their own country, usually through language, and, surprisingly, physical features, as reported by many interviewees. The second most important strategy is arriving with an address of a friend or relative, which many do, particularly the Congolese, Senegalese and Malawians. Allied to the second strategy is, thirdly, locking into an established network of migrants. The forth strategy is to find their way to church sponsored-refugee centres, such as the Jesuit Refugee Services and Mennonite Refugee Project. These services are for all refugees, but particularly those forced migrants affected by the genocide and continuing conflict in the Great Lakes region of Central Africa (Congo, Burundi, Rwanda), and in East Africa (Somalia, Ethiopia, Sudan). Malawians and Senegalese to my knowledge do not use these services. Lastly, for Muslims migrants such as Malawians from the Mangochi district, connecting and seeking assistance from Islamic charitable and welfare organizations or mosques has been a major consideration in starting to develop a new life. This also applies to the early Somali, Rwandese and Burundian refugees and migrants. It should be noted that some refugees and undocumented migrants also pretend to be Muslims in order to get priority attention from Islamic based welfare and charitable organizations.

What are the options for livelihood generation by foreign migrants in South Africa? Often denied access to jobs that they have been trained for in their countries of origin such as teachers, medical personnel, engineers, economists, and technicians of various kinds, most have turned to working for themselves in the informal sector as street traders, car guards, street hair salons, tailors and security guards. Some worked in the retail sector and construction industry as unskilled labourers. This is not to deny that many migrants come to the country without any apparent skills at all, such as some of the Malawians, thus becoming vulnerable to unscrupulous employers, who make them work under onerous conditions illegally.

The range of occupations mentioned above is not a menu of options, but rather what is available for foreign African migrants. Indeed, except for the security, retail and construction sectors, all the other occupations tend to be in the informal sector. Even in this sector migrants find it difficult to make a living. Until approximately 1984 no one was allowed to engage in informal trade on the streets of the major cities. In Durban this prohibition on itinerant street trading has a long history stretching back to the beginning of the Natal colony in the mid- $19^{\text {th }}$ century, targeting especially local black and Indian 


\section{Shahid Vawda}

hawkers. However, over the last twenty years informal trading on the streets has become an accepted and tolerated activity, and the by-laws which strictly prevented street trading and hawking were amended, and replaced by a system of issuing permits, or 'vending licenses' to trade within clearly demarcated areas on the street ${ }^{4}$. However, progressive this might seem in the face of the formal economy's inability to generate sufficient jobs to absorb the unemployed and provide an alternative to formal employment, its application has prejudiced foreign migrants from other parts of Africa. In the city of Durban foreign migrants have been denied the trading permits on the grounds that they do not have a 13 digit identity number. It just so happens that this 13 digit identity number is one that is issued and used by South African state. But the issuing of licenses do not discriminate on the basis of South African identity numbers - it merely requires an identity number, which all refugees and asylum seekers have on their 'prohibition of Aliens' document or official identity books.

Often the choice of livelihood within the range of options available depends, in the initial stages of their stay, on the country of origin, what networks of friends and relatives that they connect with in South Africa, and how long they are prepared to persevere in finding the kind of work they are comfortable with, or prepared to do. Thus one finds that many of the street traders are Senegalese and Somalis (mainly Muslim), whereas the Congolese, Burundians and Rwandans tend towards being car guards on the streets of Durban and security guards for homes, offices, factories and various institutions. Some of them run street hair salons, and engage in tailoring, as do some of the Ghanaians and Cameroonians. Malawians, because of the longer ties that they have with South Africa tend to be able to connect with a wellestablished network of their own nationals. These networks, which shall be described below, provide them with advice on employment opportunities, or access to South African employers mainly in various retailing, tailoring, dressmaking and clothing manufacturing sectors. Some Malawians have subsequently branched out to work on their own, and in a few cases actually create employment.

Using one or a combination of these strategies outlined above to settle

${ }^{4}$ For an assessment of the early strategies of the Durban municipality, towards hawking see C.M. Rogerson and D.M. Hart 'The Struggle for the Streets: Deregulation and Hawking in South Africa's Major Urban Areas'. Social Dynamics 15,1 (1989) 29-45. 
the primary requisites of accommodation and their visa conditions, they are now in a position to seek employment or to become self-employed. It is at this point that the ability to exercise their economic right to employment becomes severely limited. Unable to find employment (as formal employees) because of legal constraints, prevailing prejudices and xenophobic tendencies in the host society many of the migrants resort to one or more broad strategic options. One option is the refugee centre, a church-funded project based in the Durban Ecumenical Centre. Those who have sought assistance from organizations such as the Jesuit Refugee Services (JRS), The Mennonite Refugee Project, and the Japanese Voluntary Committee (JVC) have been mainly, though not exclusively, people from Central Africa, particularly Congolese, Rwandans, and Burundians and Ethiopians. Others such as Somalis have also sought their assistance, but have also been to Muslim organizations such as the South African Zakaat Fund, the Africa Muslim Agency, The International Dawa Movement and Islamic Propagation Centre, as well as mosques and other Muslim welfare agencies. The other option is illustrated by groups like the Senegalese, who make no use of such services for their initial survival prospects. Instead they rely on their own networks and organizational capacities to survive. Malawians make minimal use of welfare organizations initially, but do use them extensively in integrating themselves into South African society and economy. Yet, as Hagan and Ebaugh (2003) point out, migrants, 'use religion in the migration process'. Often it is part of the decision to migrate and making a living in the country of destination. And as Garnett and Harris (2013) show, such decisions and actions 'reinscribe religion into the city' and highten religious identities rather than diminish its significance.

\section{Location and Livelihoods}

In the main, many continental African foreign migrants are found in city centres because it is the only place where there are better opportunities for making a living and where they have access to resources to ensure a measure of protection. The well connected political elite and upper middle class migrants, among whom there may be Muslims that fled places like Zaire (Democratic Republic of Congo), Burundi, Rwanda or Nigeria, were able to easily insert themselves into the South African economy as business or other professionals and living in the suburbs (Bouillon 2001: 48-50). Others such as 


\section{Shahid Vawda}

the refugees from the Great Lakes area and countries such as Somalia, did not have these options and resorted to street trading, trading in flea-markets, and for the more entrepreneurial import-export businesses linked to their country of origin (for ethnographic studies of Somali migrants see Jinnah 2010; Sadouni 2014). Although many did not find it difficult to adapt to informal trading, as it is a familiar activity, it is necessary to understand that there are different categories of people involved in these activities. Firstly, there are those involved in the import-export business, but who carry out their market selling activities on the streets and flea-markets of major cities. They come, according to Kadima (2001: 102), from a number of different professional fields such as mathematics, engineering, accountancy, and pilots, as well as from the ranks of the asylum seekers, refugees and students who had to earn a living while in South Africa to sustain themselves. Unlike the elite, their residential and living conditions were/are confined to the densely populated inner cities, partly to find protection and security from the hostility of locals and officials, and partly because of easy access to their trading places in the city. In Johannesburg this means living in places such as Hillbrow, Bertrams, Berea and Yeoville. In Durban and Cape Town this meant the central business district, to lesser extent in various suburbs. Although for some this avenue of employment has not been successful, others who started modestly become successful at their business, and provide employment for at least two additional persons. But their success, despite the lack of state support for small, micro and medium enterprises of foreign migrants, often attracts the hostility of local traders who accuse them of using unfair and illegal practices, and fuels the xenophobia that prevails in South Africa (Kadima 2001: 105). In recent years some Somali have ventured out into townships to set up their businesses, only to be confronted by physical xenophobic attacks which destroyed their business premises, and some cases led to their homicide. The third broad category of immigration has been from the working and peasant classes of countries such as Senegal, Mali and Malawi. Here one needs to distinguish between the professional traders, whose informal trading is a network based on import-export business across the continent and globally, and those who are small traders but who sell goods on the street and flea-markets, reliant on local wholesalers to purchase the goods they sell, in order to make a living. Both groups remit money in dollars, or euros (in the past, francs) to their families back home, and to their respective religious and ethno-national associations. As far as educational levels are concerned, this can range from university 
graduates and professionals to illiterate peasants who are sent by their families to earn money. Both these groupings are represented by the Senegalese, and to lesser extent the Malawians. For the 'professional' international street traders among the Senegalese they have an extended global network based on the Muslim Mouride brotherhood. These traders have a double status of being traders and international migrants (Bredeloup 1995:21). The Senegalese single subsistence trader on the street also has access to the Mouride brotherhood, expressed through a community network known as the dahira, (or di'ira) and which in its local context, such as in Durban, Johannesburg, Port Elizabeth or Cape Town provides a place to meet, for prayer and the collections of funds to provide for emergency assistance to any member, and to remit funds for development projects back home. Amongst Malawians there are also those who seek and find formal employment in South Africa in vast range of occupations ranging from gardening to factory floor worker, from shop assistants to tailors and mechanics rather than as entrepreneurs.

The urban centres to which most African migrants gravitate to are not easy locations from which to make a living. It is a contested space, within which foreign migrants must also find a place to survive. The city centre, once the preserve of privileged white accommodation and economic opportunities, has changed dramatically. It now occupies the middle ground, a socio-spatial hierarchy that structures the life trajectories of different groups of people, between the townships and informal settlements on the one hand and the former white-only suburbs on the periphery on the other. The city centre in Durban is actively contested by new social forces of the post-apartheid period. On the one hand there is the Durban city council, keen to reverse inner city decline, pinning its hopes on urban renewal policies and strategies designed to target and attract affluent international consumption such as through the International Conference Centre, tourism, and the north pier and waterfront developments, and various affluent 'gated communities', while a large marginalised, but by no means exclusively black population, keen to pursue livelihood options in the city centre have become the new urban dwellers. It is into this contested terrain that foreign African migrants have found themselves.

However, some of these migrants, such as the group of Malawians under consideration, have abandoned this contested spatial terrain for residence and work on the periphery of the city, namely Mariannhill. Removing or absenting themselves from those contestations means another way of making a living: hidden, but not absent from developments in the city. On the other 


\section{Shahid Vawda}

hand, Senegalese, and to a lesser extent the Somali, other Malawians (in common with Congolese and other continental African migrants) sought to refashion their strategies to make a living in the city centre.

Given the way in which the city operated and institutionalised its rules and procedures to favour particular categories of its formal citizenry, as well as the xenophobic antagonism directed by local people against the foreign street traders, the responses of the Malawians and Senegalese migrants merits some comment. It is in the different conceptualisations of place as a strategic option by Malawians and Senegalese, and consequently the strategies pursued. For the Senegalese the city centre or the place where a market for their goods is easily accessible is important, despite the constraints imposed by the city officials, and ways had to be found around them. Also too, the lack of knowledge of places beyond the central business distict and to remain close to the ties established by the Dahira, meant that it was difficult to conceptualise a place for both residential accommodation and making a living in any other place $^{5}$. For Malawians with a long history and wider network of information about the city and its environs a move to Marianihill was not traumatic. In a sense both Senegalese and Malawians use a pre-tested repertoire of options to meet the immediate needs of living and working in Durban ${ }^{6}$. What seems to transpire here is that pre-existing cultural repertoires are made to interpret the actual existing conditions and evolve a response that circumvents the predicaments encountered by state desires for urban order and development.

The Senegalese and the Malawians illustrate very different options for survival, and re-constituting themselves as survivalist entrepreneurs, workers, family members and communities. Religion in this set of circumstances, per force, plays its role as a basis for social solidarity and welfare among Muslims from various particular countries, under circumstances that are difficult to

${ }^{5}$ As their knowledge of places to trade extends beyond the central business district and indeed the city boundaries, new conceptualisations of places come into being and also new strategies of where and how to reach these new places and engage in trading. One such place was Mandini some $80 \mathrm{~km}$ north of Durban where a weekly market was attended by some Senegalese.

${ }^{6}$ For an account of how Senegalese organization, such as the Dahira, operate in a number of different contexts see Buggenhagen (2010). For a fuller ethnographic account in the European context see Carter on Senegalese in Italy (1997). 
negotiate. Virtually from the moment they arrive, they rely on their own networks and entrepreneurial experience to fend for themselves. While the Senegalese have opted to live and work in the city centre, the high cost of living in the city centre meant that many Malawian Muslim migrants exercised the option of moving their residence (and in some cases their enterprises) out of the city centre to the margins of the Durban Metro region such as in Mariannhill. In this sense their actions represent two very strikingly different responses to the vulnerable position that migrants find themselves in. It also means that such options illustrate possibilities that are not structurally predetermined, but very much a way of making assessments of all relevant variables and pursuing such strategies that may benefit them optimally.

Nevertheless, it also represents, in the case of the Senegalese and Malawians, very specific responses from within their respective social positions, particularly in the way religious affiliation is used as a resource - as spiritual and ideological sustenance, as well as strategic physical resource - in order for them to survive, and indeed prosper beyond merely survivalist livelihood strategies. It is to these issues that I now turn.

\section{Networks, Religion and Livelihoods}

One of the striking aspects of Malawian migrants is that despite the restrictions of Apartheid they have a long-established network of people that they can connect with when they arrive in Durban. The Senegalese on the other hand have a long experience of being international traders, no historical experience of migration to South Africa, but do have a model of networking that is quickly established and applied in the specific circumstances that exist. However, such resilience of these two archetypes depends on the kinds of resources or 'assets' that are available. As Moser (1996) has argued the more the resources or assets that the poor and marginalized have, the greater the chance of survival, persistence, resistance and recovery from poverty. One set of those resources are, in the case of migrants, their self-defined networks of mutual assistance provided by such communities to those in need. There are limits to that assistance. The second set of resources are their identities which are closely tied up to the way the state recognises them, and the associated rights, or lack of such rights, and their reception and perceptions of themselves as belonging to a particular religion, nationality and sometimes race. The third set of 


\section{Shahid Vawda}

resources or other assets is basic public infrastructure provided by the local state in which both the living and working conditions of migrants prevails. The combination and use of, or inability to use, available resources of Senegalese and Malawian Muslim migrants is explored below.

Before I continue to describe the networks and identities of the Senegalese and Malawians, I should define what networks are and how, in these cases, they link with the question of identity. Eades (1987:8) describes a network of migrants as a 'spider's web', a veritable collection of connected people. Portes and Walton have described this circulation or network of migrants as a response to capitalist development as 'tie-in groups distributed across different places maximising their economic opportunities through mutual aid and multiple displacements' (1981: 60) (my emphasis). When such linkages are maintained, renewed and reconstituted, whether through social ties and/or the passing of material goods from one locality in a nation state to another, identities are constructed and re-appropriated through their daily practices to maximise their specific strategic intentions, whether these be in the context of families, organisations, economic activities, or business and financial investments (Basch, Schiller \& Szanton-Blanc 1994: 28-30; Portes 1997). In applying these insights to the networks that Malawians and Senegalese have built up within South Africa, and Durban in particular, migrants' networks should be seen as part of a process which constructs, reconstructs, and appropriates different aspects of their social relations, in order to insert themselves into the new local economy and society, and simultaneously retain contact with one or more places of origin. In other words they make the space for simultaneous living in two or more worlds in which their practices, social relations and multiple identities are embedded. One of the obvious outcomes of these networks or spider web connections is the multidirectional flow of ideas, information and events and the entrenching of migratory contacts, or transnational contacts and identities.

\section{The Senegalese: Living and Trading in the City Centre}

Most Senegalese, when they arrive make contact with fellow Senegalese. Once they register with the Department of Home Affairs, usually as asylum seekers, they begin the process of learning to trade on the street. If they do not have the start-up capital, friends or relatives provide a small amount of start-up capital 
for them to buy goods to sell on the streets, or share in some street enterprise before starting on their own. Sometimes the initial capital is made available through the Dahira organization. The critical point is to find a place to trade, avoid harassment by officials and the police, pay back the loan, accumulate and remit money and contribute to the Dahira. Many Senegalese, in the late 1990s and early 2000's attempted but failed to obtain the license or permit to trade on the street. Some have been lucky enough obtain a trading stall at one of the permanent flea markets in the city centre.

The flea markets are controlled by private entrepreneurs who rent out stalls or space to traders, making access to them outside the direct control of local government policy, by-laws or officials. Both Senegalese and Somalis have attempted to circumvent the permit system by using a proxy to apply for a license. Some, although not all, have been successful and have employed their proxies, usually local women, as sales assistants. However, securing a permit through proxies does not end the harassment by the police and local government officials. Some local traders have alerted the authorities to those who have been able to obtain licenses in this way. This has been encouraged by the Durban Chamber of Commerce and Industry (Digest October 1998). City police and inspectors have taken away their licenses on the grounds that they have been obtained fraudulently. This has forced most of the Senegalese to continue to trade illegally on the streets, particularly in central business districts. Since the late 1990s there has been constant pressure on the Senegalese, as well as other street traders to move their street business to less lucrative sites on the margins of the CBD. This policy of harassment is pursued with particular vigour and at times brutality. The problem with this approach is that while it plays into prejudices and racist attitudes of all sectors of the South Africa population, including those unreconstructed city planners, officials and politicians, it obscures several crucial issues concerning human rights and the development of the city.

Quite clearly having the right to seek and engage in meaningful employment whether as refugees or asylum seekers is being violated. While in purely technical terms to overcome this violation simply means an extension to legal immigrants the right to obtain a permit, the approach of the city to hawkers brings to light a broader set of development and governance issues. Immigrants live and work in the city. Their presence, both physically and socially, including the use of places of worship such as Mosques is unmistakable, and their use and contribution to the resources of the city makes 


\section{Shahid Vawda}

it a concern for the city authorities ${ }^{7}$. This should not be interpreted to mean that access to the city for African foreign migrants, but rather there should be recognition that such immigrants and migrants are not going to disappear. If indeed the local government deems it fit to cut off access by constant harassment of those street traders that seek to engage in legitimate and open informal business it can have the adverse effect of driving such business underground. This would add to the burden of crime rather than prevent it. Alternatively it would mean local government having to provide shelter, welfare services and some level of gainful employment. Thus far the city authorities have largely been reactive, and have left the provision of any services and assistance to refugees and political asylum seekers to nongovernmental and religious organisations and private initiatives ${ }^{8}$.

There are of course potential benefits to the city if a more constructive approach is taken to street trading by foreign nationals. Firstly, most of the Senegalese and the Somalis, and many local traders sell leather goods (bags, belts, shoes, watch straps) watches and clothing. These goods are obtained from a variety of sources, mainly from their own trade networks based in other major cities in South Africa, and from their contacts in Europe, America and Asia, and from local factories, local wholesalers or from foreign importers such as the Chinese who in turn import their goods from much the same sources. Given that we are living in a globally competitive environment, the networks and contacts of global trading established by the immigrants are a resource to be cultivated, rather than restricted. Furthermore, there are the trade networks that extend into Africa, albeit small by comparison with large multi-national companies, but nevertheless a point of departure for a port city to extend its trade network to an untapped market. Naturally this requires it to shed its Eurocentric vision of trade as primarily connected with Europe and America, and that small or micro enterprises are a matter of only an internal survivalist and tourist market. City authorities have largely been reactive to foreign migrants, rather than seeing an opportunity to use their presence to as part of revival and upgrading of the urban centre. Indeed it may be argued that by not recognising the potential revenue generated by granting immigrants the

${ }^{7}$ One informant refers in a self-deprecating way to himself and his fellow Senegalese as '.. black and ugly. It is easy to see who we are'.

${ }^{8}$ One such initiative is sponsored by the Japanese Voluntary Service, and another by the Catholic Church. 
required trading permits, they reduce the revenue generated from immigrant street traders who are willing to pay these costs in order to secure a stand to support their business enterprises. City authorities have also left the burden of the provision of services and assistance to refugees and asylum seekers to nongovernmental and religious organizations and private initiatives.

For migrants such as the Senegalese and Malawians the lack of state support structures has not prevented them from participating in the local economy. The Senegalese traders are known to be astute entrepreneurs who have been able to turn areas of other cities which have previously been thought to be dead into thriving markets (Stoller 1996; 2001). The distinctive entrepreneurship of the Senegalese lies in a number of factors. These are their reliance on their own internal network of local, national and international contacts to source the commodities they sell at the best possible prices, the ability to pool residential and household requirements, the absence of family structures ${ }^{9}$, and a single minded dedication to the tasks.

Their dedication to their entrepreneurial activities also draws from religion, that is, the interpretation of Islam by the Sufi saint Sheikh Ahmadou Bamba, which inculcates an ethic of resilience, frugality and honesty (Kariya 2012). It appears that their profit margins are made on their turnover, and not solely on a mercantile principle of buy cheap, sell competitively. From my observations they do not undercut the prevailing street prices of commodities and thus also circumvent such potential criticism. Hence, it is the skill of marketing entrepreneurship that is of vital importance in their successful business practice. However this presupposes a stable point on the street to build a client/customer base. Thus there was a great deal of frustration with the policy of the Durban city authorities which denies them trading permits and requires them to be constantly moving, thereby undermining their ability to do business. Indeed, their lack of economic rights (as an aspect of their human right to trade, occupation and profession ${ }^{10}$ ) has forced them to seek legal advice. There were three options available: seek relief through direct legal action (a class action launched through the High Court) or negotiation with city officials and politicians over their plight. The Senegalese are more disposed to negotiation so that less unwanted political attention is drawn to themselves. Negotiations, inevitably, lead to a second strategy of forming wider alliances

${ }^{9}$ Most married Senegalese migrants do not have their wives with them.

${ }^{10}$ The Constitution of the Republic of South Africa, Chapter 2, clause 22. 


\section{Shahid Vawda}

and co-operation with other groups of migrants in similar situations, and organisations that deal with refugee issues, as well as local street traders organizations in an attempt to demonstrate to city officials that their concerns over their street trading rights affects a wider constituency than a specific foreign national group. A third option was to abandon trading on the streets, and either move into more formal trading patterns, or leave to other pastures. Many Senegalese chose to leave, many returning to West Africa, to countries such as Cote d'Ivoire (despite the political turmoil), others to Dakar to weigh up their next options, and some to the United States while others continued to trade in flea markets and establish formal retail businesses. In this movement to and fro the Dahira continued to function as the organisations that oversaw the exit from South Africa for many, but continues to sustain their everyday day and collective identities through annual religious ritual events such as the Margal.

\section{Malawians: Living on the Urban Periphery}

Compare this set of circumstances with that of Malawians living on the urban periphery in an area known as Mariannhill, some $35 \mathrm{~km}$ from the centre of Durban. Some 20 years ago Mariannhill was a peri-urban settlement (more rural than urban) of mixed races. It was an area where the really poor working class who could not afford a house in the urban townships lived alongside small scale rural farmers, and consequently was a very underdeveloped area where many did not have basic essentials such as running water and electricity. Since 1994 it has seen the benefits of the Reconstruction and Development Programme (RDP) of the first post-apartheid government where land was bought from landlords ${ }^{11}$, developed and given with freehold title to the occupants. This is the area that Malawians have begun to populate and live in since at least the 1990s.

${ }^{11}$ The land on which the Malawians lived was apparently owned by an Indian Muslim, a Mr. Moola, who according to my informants donated the land to be developed. The land was taken over by the Inner West Council of the Durban Metro and developed with Reconstruction and Development Programme funds. The land was cut up into residential plots and freehold title was given to the residents. A road system, water and electricity were also supplied. 
These Malawians, as I have indicated above, occupy not just a different physical space in the city, but pursue a different strategy of participating and making a living in the city. Like the Senegalese they rely on their national identity to enter the country, the difference being that they are treated with less suspicion than other African nationals. They are aware that a declaration to an immigration official that they are seeking work in South Africa would be a strategic mistake. Thus obtaining a tourist visa is the least problematic means of entry because they can easily satisfy the test of a name and an address of a relative or friend in South Africa given the long term contact between the two countries. In any event Malawians are entitled, in terms of recent policy changes (not legislative) to admit people from within the Southern African Development Community (SADC) greater ease of access and residential rights to their respective countries. For example one Malawian informant showed me his resident permit and passport which was stamped: 'Malawian citizen, resident in South Africa'. Unlike the Senegalese who rely heavily on their own internal network of Senegalese, the Dihira, for support, the Malawians rely on a variety of different strategies to survive. The fact of nationality is important for entry, (the long term relationships between the two countries and membership of the SADC) but once inside the country, religious community of Muslims, work skills, length of stay and marriage to locals are important considerations in their survivalist strategies.

Religious affiliation operates in two ways. Firstly, those Malawians living in Mariannhill are all Muslims, mostly Yao. Apart from the fact of being Malawian Muslims, they all live in a single neighbourhood, have their own Cheikh, mosque and madressa or Quranic school. There is a sense of cooperation and responsibility among the inhabitants, collectively known as the Greyvillea Muslim Association ${ }^{12}$ for receiving migrants from Malawi into their community. But primary responsibility lies with the migrant and his or her hosts to accommodate, provide initial sustenance, and direct the migrant to those who might assist in finding work. Secondly, Muslims in Malawi have established long term relationships with various local South African Islamic

${ }^{12}$ I do not want to exaggerate this sense of community because at the moment they are a community in a religious sense. This takes on a significant meaning when everyone else around them is either Hindu or Christian. Furthermore they often express the need to organise themselves to petition the local council for a facilities such as a clinic and crèche, and to assist new immigrants. 


\section{Shahid Vawda}

charity and welfare organisations that have been operating in Malawi. In the main these organisations are mostly based in Durban, such as the International Dawa Movement and the International Islamic Propagation Centre, which are supported by local Indian South African Muslims. These contacts are reciprocated when Malawians come to Durban. For example when one of the few woman Malawian migrants, Kiri Banda, said that one of the reasons she was able to come to Durban was because she had the address of a Muslim Indian woman who had engaged in Islamic missionary work in Malawi, and was able to stay with her until she was able to fend for herself. The missionary apparently had worked for Islamic Propagation Centre ${ }^{13}$. She also had the address of her brother, but did not reside with him initially (Interview 27 July 1999). The second example is when a Sudanese-trained Islamic scholar, Said Muhammad, came to Durban to minister to the needs of Malawian Muslims. He was employed by the International Dawah Movement, also based in Durban, as a religious teacher and leader among the Malawians of Mariannhill on the grounds. As stated by Said Muhammad, 'Malawians [in Durban] had limited knowledge of Islam. The response was very good. Malawians began to learn new aspects of Islam'. He then began to convert many of the 'Zulu' in Mariannhill (Interview 8 July 1999). His employment as a religious teacher was prompted by the intervention of another Malawian who had migrated to South Africa in 1945, Moses Chindu, and who had close a relationship with Dr Dadoo, an official of the International Dawah Movement. This served as the basis of his considerable community involvement, and network of friends and contacts, not only in religious matters, but also in community matters such as providing literacy classes for the youth and the translation of religious texts from English to Zulu (a language which he also learnt to enable him to proselytise among the Zulu speakers of the community) ${ }^{14}$. The irony of a Malawian conducting proselytizing activities in South Africa, where local, mostly Indian Muslim organizations have failed, is not new (see Vawda 1994).

What these examples suggests is that the decision to migrate, apart from the sense that prosperity exists in South Africa, is informed for Malawian

${ }^{13}$ The Islamic Propagation Centre is based in Durban and apparently carries out missionary work in various parts of Southern Africa.

${ }^{14}$ This also provided the good Sheikh with the possibility of engaging in some entrepreneurial activities of his own, unrelated to his religious leadership, and remitting funds to start businesses in Malawi. 
migrants by the notion of the Umma - that a community of Muslims exists in South Africa, thus triggering actual migration. For example S. Banda who found himself in dire financial straits in Malawi decides to migrate, with a companion, to find work to feed his family. He states:

I had no plan to come to any person. I am a Muslim and I was going to rely on other Muslims to assist me. After I got off the taxi at Umgeni Road, I saw a Mosque [the May Street Mosque]. It was Esha time [the evening prayer]. I saw some people coming out of the Mosque. I simply went to them and greet them 'As salaam wa alakum'. They had to respond. I asked them to tell me where 155 Grey Street was [the Grey Street Mosque]. Someone took me there. ...This was the only address I had. I met an old man there who was from Malawi. He worked in the Mosque. He helped the two of us (Interview May 1999).

It is in the context of these contacts that the Malawian immigrants are able to find assistance and work from among the local Muslim community. Work opportunities range from casual unskilled jobs to regular fixed salary work as machinists, tailors, shop assistants and domestic servants. As Shafik, a Malawian Muslim said 'As Muslims they give us work, but they also don't pay well. We must thank Allah they give us the chance to get some money, but it is too little'. However, another Malawian, Sarah, qualified this by stating that even if wages are low by South African standards, it is much more than they would earn in Malawi. For example, a recent migrant of three weeks, Jimo, said that it took him three months to earn enough money, $\$ 75$, just to enable him to travel from Malawi to South Africa. Even under exploitative conditions such as for domestic servants it would take less than two months to earn that amount in South Africa.

But it is the possibility of living in the urban periphery, with lower accommodation and subsistence costs and with a community support system that enables them to survive on very low wages. But for them it is not just another poverty trap. Like the Senegalese who are able to survive on very small profit margins because they live communally in run down city centre apartments, surviving in the semi-urban area of Marainnhill enables them to accumulate some surplus funds over a two or three year period. The question is what do they do with these accumulated funds? In the case of one of my key informants Shafik, set up his own tailoring business in Marainnhill, after many 


\section{Shahid Vawda}

years of working in a clothing factory and various tailoring establishments. Working from home he was able to accept contract work from some of the Indian owned clothing factories and retailers, as well as casual everyday business. Another, Kenneth and his friend Ebhrahim sew pinafores for sale to local women street traders. Other Malawian migrants, it seems, buy various goods that are scare in Malawi: clothes, electronic equipment, household equipment, cosmetics etc for re-sale in Malawi. Others, such as the recent migrant, Jimo, are here as target workers. They have in their minds what they want to pursue as their main subsistence or livelihood activities in Malawi, but need to obtain the necessary start-up capital or commodities by working in South Africa, and then returning. Thus for some the whole process of migration, work, accumulation and return could be repeated as need arises leading to a pattern of oscillating international migration between their countries of origin and South Africa.

These case studies suggest that for African Muslim migrants, particularly the Senegalese and Malawians, that while they are economic migrants, asylum seekers and refugees, who retain contact with their countries of origin, and may wish to return home, they are also a set of diverse inhabitants of the city with a diverse set of expectations in terms of access to resources, jobs, services and rights. Despite being victims of migratory processes and xenophobia, they have developed a creative network of people and incipient associations, based on their religious and ethno-national characteristics as is normal for such migrants' world-wide, and upon which they rely on to make a living and assimilate themselves into the host society and economy. Their ability to find ways of making it possible to survive and many cases prosper in social and economic terms, presumes some level of organizational initiatives, and opens the way for its development. There are a number of issues which these Muslim migrants' social and economic practices raise, which are discussed below.

\section{Strategies, Identities, and Prejudices}

Both the Senegalese and Malawian migrants evolved, and continue to evolve, strategies that take into account the constraining variables on their livelihoods. The larger situational context are the state, local communities or places of residence and their relationships with their local co-religionists. Some 
strategies used, such as religious affiliation enable both to produce a set of complementary ties that initially allow them to survive the strangeness of a new city and then integrate themselves in the ways of living and working in the city. At the level of actual work these include their trading partners and competitors as well as their own networks of contacts that incorporate relationships based on national, ethnic, town, village, neighbourhood contacts, as well as affective ties of friendship, family and kinship. Creative tactics also respond to daily engagements with state bureaucratic strictures and demands (such as permits or trading restrictions), avoidance and circumventing police and immigration raids, xenophobia, disgruntled market competitors, among others.

\section{Organizational Strategies}

When comparing the two Muslim migrant communities and the use of religion in their livelihood strategies, it is quite clear that Islam is worn on the sleeves of the Malawians out in Marainnhill, and is clearly demonstrated in the building of a mosque and madressa. Although the Senegalese do not outwardly display the trappings of their religion, this does not mean that they do not practice their religion. Prayer, for example, is not apparent because many of them prefer to pray in the safety of their apartments, rather than attend the mosques which then openly invites prejudiced comments from black South Africans, who still associate Islam with an 'Indian religion'. However, Malawians have used their religious activism and contacts among local Muslims to access assistance upon arrival, employment opportunities and as benefactors to build mosques such as the one in Marianhill, as well as the donation of land for residential purposes. The price for such close association may be tactically a creative dependence on patronage. The Senegalese on the other hand have not taken this route, relying rather on their own resources to provide for themselves through their street and other trading activities. Senegalese resources are not just material and financial ones, but the considerable wider network of national and international links that they have in Africa, Europe and America through their mutual aid society Dahira Mafathihul Bischri. In recent times the Senegalese have made contact with local Muslim organizations, primarily to find suitable sites to host heir annual Magal ritual celebrations. However, this was on the terms that they would pay 


\section{Shahid Vawda}

for the services rendered by the local Muslim organizations, rather than patronage. In some ways the separate organisational structures that the Malawians and Senegalese have evolved, echoes research in Europe that shows the ethno-national origins and character of Muslim organizations (Buijs \& Rath 2006: 15).

\section{Identities: State, Place and Prejudice}

While there are organizational strategies that suggest a certain permanency of continental African, and particularly Muslim presence, the very process of migrating, and the retention of ties back home means that new fluid identities were forged. Foreign migrant identities are shaped from the moment they arrive at border posts. From the perspective of the foreign migrant state power is visibly apparent in the whole apparatus of borders, passport controls, issuing of visas, permits and rights and obligations attached to it. The local state on the other hand has reacted in mainly negative and hostile ways in the contestation for urban space to work and live, or alternatively trying to ignore that they exist. However, identities are also powerfully shared by those that they interact with, in this case principally their co-religionists and the local populations. These are analysed below.

\section{Place and Identity}

There are different aspects to the notion of place. In the context of pursuing livelihood strategies place of origin, place of destination and use of identity and networks in these places are important to consider. Like most continental Africans such as the Senegalese (and others from Congo, Nigeria, etc.) they rely on their national identity to enter the country, the difference being that they, the Malawians, are treated with less suspicion than other African nationals. Secondly, while many Senegalese claim asylum status, Malawians cannot make this claim. Asylum seekers and refugees have a certain ease of entry, and unlike in other African countries have freedom of movement to find work as they are not confined to refugee camps. In any event Malawians are entitled to visitor entries, which are easier to obtain in terms of recent policy changes (not legislative) to admit people from within the Southern African Development Community (SADC) with greater ease of access and residential 
rights to their respective countries. As Said Muhammad stated in recounting his experience at the Zimbabwe-South Africa border:

The treatment at the border was very good. There is only one condition: do not say you are coming to look for work. Say you are visiting. You see, in the SADC non-citizens like Malawians have special permission to live here. You can even get an identity book, but you are a non-citizen.

What is clear is that migrants, whatever their own or other southern African countries currently offer in the form of livelihood possibilities, see South Africa as the best possible destination. Yet entry as a national of another country does not imply that every migrant wants to settle here permanently. Clearly some do, but retain their ties to their places of origin, and intend, at some future and unspecified time, return to their home - the village, town or city of their country of origin. But they still hold the option of coming back as migrants to seek work for specific purposes - accumulate capital, buy goods for trading or to support a family or business enterprise in Malawi. Official national status, the country of origin, becomes another means to access other livelihood possibilities in other SADC countries, but principally South Africa. These Muslim African migrants are transnational migrants.

Upon entry different identities are adopted in relation to the place of accommodation and work. The fact of nationality is important for entry (the long-term relationships between the two countries and membership of the SADC), but once inside the country, religious affiliation, village or town of origin, work skills, length of stay, and marriage to locals are important considerations in their survivalist strategies. Consideration shall be given to these other identities, especially religion and skills as part of their livelihood strategies below. What is important to highlight here is the fact that many Malawians opt to live in a relatively underdeveloped part of the city. Unlike the Senegalese, and other migrants such as the Somali, Nigerians, Congolese, Burundians and Rwandans, whose livelihoods are integrally bound to the centre of the city, the Malawians who live in Mariannhill do not just occupy a different physical space in the city, but pursue a different conception of participating and making a living in the city. Being physically far from the city centre gives them a level of protection from constant raids from the police and immigration officials, as well as enabling a most modest standard of living. 


\section{Shahid Vawda}

Furthermore there is a sense of community that has developed among the Malawians, as is evidenced by the building of two mosques and a madressa (an Islamic school) to educate children and adults about Islam, and a network of contacts allowing for a flow of information that enables Malawians to access jobs and economic opportunities. However, unlike the Senegalese who rely heavily on their own internal network, the Dahira, for support, and to which they contribute financially the Malawian networks are less formally organised. They do rely on their networks, tactically as points of contact when they first enter the country and to access their first jobs, but they also pursue livelihood possibilities without their networks. However it should be noted that not all Malawians pursue this strategy of place and identity, such as Mariannhill, national of Malawi, native of Mangochi district, and /or Muslim, or friend and relative from town of village of origin, as the only means of entry and survival as foreign migrants. A significant number do live in areas such as Overport (and the city centre), a high-density residential area of mainly high-rise apartment blocks. Whereas Senegalese are conspicuous, at least initially, by their inability to communicate in either English or one of the local indigenous languages, Malawians speak English, and make the effort to learn Zulu, which allows for a level of integration within the community or residential area of occupation, and easier working relationships with local people.

\section{Interactions with Non-Muslims: Coping with Prejudice}

It has been well documented that continental Africans are often surprised at the xenophobic and racist vitriol directed at them by South Africans, particularly black people. The most common term used by black South African for continental Africans is 'amakwerekwere' - reference to the apparently unintelligible languages that they speak. Apart from verbal abuse, they are often accused of stealing jobs, being a drain on the resources of the country and taking the local women, as well as being involved in crime and drugs. Some migrant national groups such as the Nigerians and Congolese have reacted to such prejudices by defending their national identity, thus reinforcing a cycle of boundary maintenance, stereotyping, and promoting scapegoating, among South Africans in a context of sluggish economic growth and high unemployment (Morris 2001: 75-8). Although unemployment and moderate growing economy combined with effects of 
isolation from the rest of the continent have contributed to a less than adequate response by local people to the problems of other Africans, what is interesting about the Malawian and Senegalese responses to xenophobic and racist verbal abuse is that it has not led to an intensification of nationalism, as is the case with the Nigerians and Congolese, but rather placing the accent on religious and ethnic identities. Malawians and Senegalese while they do experience xenophobia and racism, have developed a different approach to dealing with such prejudices. In the main it has been less openly hostile, and more cautious. As Said Muhammad, a man of measured words, said of South Africans:

I will never forget this country when I go. Generally the people in South Africa are good people. But sometimes they call us kwerekwere. But mostly they are good people (29 July 2001).

\section{Working and Trading with South Africans}

This generosity towards South Africans by migrants such as the Malawians must be placed in the context of their participation and contributions to the economy and society of South Africa. In a study done by Rogerson of immigrant entrepreneurs (i.e. informal traders) in Johannesburg in 1996-97 it was found that they contributed 'to the revitalisation of the declining economy of the city centre' and consider Johannesburg a city 'full of opportunities and appropriate for doing business' (Rogerson 1997: 9). It would be similar for other urban centres as well. Apart from internal trading there is also the consideration of cross border trade and remittances to their home country. Depending on their work situation and income earned nearly all migrants send remittances back home. Contrary to popular perception this is not a removal of a substantial portion of income and hence vast sums of foreign exchange from the economy. One main reason for sending remittances is to support a family back home, but other reasons are to raise sufficient capital to start their own enterprises in their own countries, thus expanding international trade. (For trade with Malawi, see Anderson 2006.) The cross border trade in fact supports the manufacturing sector of the economy. Many either bring money to invest, to buy or to sell arts and craft goods in South Africa, and in turn use the money earned to buy South African manufactured goods to sell in their respective 


\section{Shahid Vawda}

countries. Contrary to popular belief, most migrants are not a drain on society. Thus not only do foreign migrants support themselves, thus mitigating the alleged drain on South Africa, but many such traders or entrepreneurs on the street actually employ some local people. Furthermore, working and learning different skills also enables them put into practice these skills in their own country.

\section{Rights to Work and Live}

As stated above local authorities such as Durban have largely reacted to foreign migrants, usually in hostile and negative ways, often on the assumption that foreigners are to blame for a range of inner city problems. Thus, by extension, foreign migrants are an irritant to be ignored and excluded from developmental plans of the local state, and therefore marginalized. However inappropriate the local state authorities responses might be from a human rights perspective, it cannot be assumed that in the future such authorities would want to exclude migrants in some kind of formal local enfranchisement process. There are three reasons why this is an important consideration.

Firstly, migrants such as the Malawians and Senegalese particularly those who have been here for long period of time and who have married locally can claim residential rights. In both the cases of the Senegalese and Malawians there are those, who despite the problems of xenophobia, hostility and intolerance, and associated problems of finding employment and living spaces, are beginning to see their stay in South Africa as more long term, perhaps even permanent rather than transitory, short term, or temporary and is evidenced in the case of the Senegalese by the purchase of a house to establish a permanent base for the dihira, and the beginning of establishing formal business premises. Some Malawians, such as those on in the outskirts of the city, have benefited from local government development initiatives. They cannot simply be excluded from local decision-making processes. More to the point is that their conceptualization of place has begun to change from one severely proscribed by what was initially understood as opportunities limited by a set of constraining variables dictated by state and local people, to one where with the required maneuverers and manipulations are understood, familiar and established.

Secondly, the Muslim Malawians have also benefited from their close 
associations with other powerful segments of the local population such as the local Muslim welfare agencies and business elites to access employment opportunities and as benefactors for mosques built in Mariannhill. The building of the mosques and the provision of religious instructors have led to greater stability within the Malawian community. Although the price to be paid for this may be dependency on patronage of the Muslim elites in the city centre in the future, the process of entwining Malawian migrants to the local business sector cannot simply be undone or ignored. The fact of dependency (and possibly exploitation) co-exists with the use of religious affiliation to strategic and tactical gains.

Thirdly, all Malawian and Senegalese (as well as other foreign African migrants) in Durban, who have some stake in the economy, either as employees or as self-employed small scale entrepreneurs, might wish to be included in some form of local representation as to their economic rights. Furthermore, there are the trade networks that extend into Africa, albeit small by comparison with large multi-national companies, but nevertheless a point of departure for any city to extend its trade network into an under-tapped market. But a wider vision of developing trade networks through small scale enterprises assumes that foreign migrants may want to be included in some form of representation, particularly as to their economic rights to work either as employees or as selfemployed small-scale entrepreneurs. For the city to acknowledge the growth and development potential that lies locked by discriminatory practices against foreign small-scale entrepreneurs means to confront the question of rights of foreign migrants, and their incorporation in the governance of the city.

\section{Diversity and Tolerance}

I mentioned above that African Muslims undermine the notion of Islam and Muslim as a racial stereotype, affirming the idea of toleration of a diversity of religious beliefs and practices. But more importantly, the very existence of a plurality of African Muslims prompts a debate about the nature of multiculturalism in South Africa and the spreading of xenophobia and noninstitutionalized racism. However, the question of African Muslim migrants' susceptibility to xenophobic attacks does raise critical questions about defining political equality in terms of individual or groups rights. Should the state give unqualified support for the protection of minorities? Or uncritical support to 


\section{Shahid Vawda}

the spreading of religious dogma? How does one define who is a Muslim, or belonging to a Muslim community? How can diversity or pluralism be compatible with liberal individualism? How can diversity be legitimated without reinforcing cultural stereotypes and racist assumption of 'the Other'. It is not merely the production of difference, a fact that is well and truly valorised in South Africa, but that such differences, produced in multiple ways, that is possibly indexical of issues of greater complexity than tabulating differences and expressions of tolerance. Thus the presence of foreign African Muslims raises many more issues of great complexity than simply their presence.

\section{Conclusions}

It is evident that African migrants arrive in the city with hardly a clear idea of what it is they are going to do to make a living, except that somehow it must be better than what they left behind. Yet at the same time they try to make sense of their new environment. Religion certainly is used in coming to terms with their new environment, but also in making sense and creating a new everyday practice of a living in the city within a highly differentiated urban population.

The Malawians and Senegalese present a picture of industrious petty entrepreneurs and workers engaged in a diverse set of occupations pursued with deft and tact in the face of hostility. While the Muslim Malawians are removed from the everyday contestation of physical space in the city centre both with other street traders, city officials and the police, these are precisely the issues and problems that plagued the Senegalese. This in turn prompted many Senegalese to find new strategies and tactics of coping with what they perceived as discrimination and prejudices to their very being or return home, or migrate to other parts of the world. While entry into South African seems almost unproblematic, it is through the use of their networks, that entry into the local economy is realised, and depending on the opportunities presented, making good their original objectives in migrating to Durban, albeit making the necessary tactical changes in the situations they find themselves. But they do face problems with xenophobia and racism being among the most serious. These prejudices directed at them do impact on the way they operate in securing for themselves accommodation, livelihoods and the practice of being 
Muslims. But in their several other identities as Muslims, traders, employers, employees and residents they play profoundly different roles as they begin to contest and subvert their all-consuming subjected identity. On a broader level, as religion and other representations evolve, appropriating the urban contexts and changing it, bringing new vitality to urban existence and pose new challenges to local authorities, provokes challenges to the narrative that the city is a place of one dimensional inclusiveness.

\section{References}

Albertyn, C. 2008. Beyond Citizenship: Human Rights and Democracy. In Worby, E., S. Hassim \& T. Kupe (eds.): Go Home or Die Here: Violence, Xenophobia and the Reinvention of Difference in South Africa. Johannesburg: University of Witwatersrand Press.

Anderson, J.A. 2006. Informal Moves, Informal Markets: International Migrants and Traders from Mzimba District, Malawi. African Affairs 105: 420.

Appadurai, A. 1995. The Production of Locality. In Fardon, R. (ed.):

Counterworks: Managing Diversity of Knowledge. London: Routledge.

Basch, L., N. Schiller \& C. Szanton 1994. Nations Unbound: Transnational

Projects, Post-Colonial Predicaments and Deterritorialized Nation

States. New York: Gordon and Breach

Bangstad, S. 2007. Global Flows, Local Appropriations: Facets of Secularization and Re-Islamization among Contemporary Cape Muslims. Amsterdam: University Press.

Bouillon, A. 2001. African Francophone Migrants to South Africa: Languages, Images and Relationships. In Morris, A. \& A. Bouillon (eds.): African Immigration to South Africa: Francophone Migration of the 1990s. Pretoria: Protea and IFAS.

Bredeloup, S. 1995. 'Sénéegalais en Côte d'Ivoire, Sénégalais Senegalais de Cote d' Ivoire'. In Bredeloup, S. (ed.): 'Dynamiques migratoires et recompositions sociales en Afrique de l'Oest'. Mondes en Déeveloppement 23,9: 13-29.

Brenner, L. 1993. Muslim Identity and Social Change in Sub-Saharan Africa. Indiana: Indiana University Press.

Buchanan, I. 2000. Michel de Certeau: Cultural Theorist. London: Sage. 
Buggenhagen, B.A. 2010. Killer Bargain: Global Networks of Senegalese Muslims and the Policing of Unofficial Economies in the War on Terror. In Makhulu, A., B.A. Buggenhagen \& M.S. Jackson (eds.): Hard Work, Hard Times: Global Volatility and African Subjectivities. University of

California Press, ebooks:- http:www.scholarship.org/ug/item/246027X0. Buyer, M. 2008. Negotiating Identity and Displacement among Somali

Refugees of Cape Town. South African Historical Journal 60,2:226-241. Buijs, F. \& J. Rath 2006. Muslim in Europe: The State of Research. IMSICOE working paper. Available at: http://users.fmg.uva.nl/jrath/events.htm.

Castles, S. \& P. Spoonley 1997. Migration and Citizenship Asia-Pacific Migration Research Network. Auckland, New Zealand: Massey University.

Carter, D. 1997. Senegalese in Italy and the New European Immigration. University of Minnesota Press.

Chirwa, W.C. 1997. No TEBA .... Forget TEBA: The Plight of Malawian ExMigrant Workers to South Africa, 1988-1994. International Migration Review 31,3:628-654.

Cross, C. n.d. The City as Destination: Migration Trends in the Durban Metropolitan Area Based on the 1999 Quality of Life Survey. Maurice Webb Rural-Urban Studies Unit, University of Natal.

Crush, J. 1997. Temporary Work and Migration Policy in South Africa. Briefing Paper for Green Paper Task Team on International Migration. Available at: www.policy.org.sa:80/govdocs/greenn-papers/migration/ crush2html.

Crush, J. (ed.) 1998. Beyond Control: Immigration and Human Rights in a Democratic South Africa. Canada: IDASA and Queen's University.

Crush, J. \& V. Williams 2002. Transnationalism and African Immigration to South Africa. SAMP, Migration Policy Brief. Available at: http://www.queensu.ca/samp.

Dagnino, E. 1994. On Becoming a Citizen. In Benmayor, R. \& S. Skotnes. (eds.): Migration and Identity. Oxford University Press.

Danso, R. \& D. McDonald 2001. Writing Xenophobia: Immigration and the Press in Post-Apartheid South Africa. Migration Policy Series No 17, Southern African Migration Project. Available at: http://www.queensu.ca/ samp/publications/policyseriess/policy17.htm.

De Klerk, M. 2002. HSRC Press Release: Estimations of 'Illegal Immigrants'. 25 April 2002. Pretoria: HSRC Press. 
Durban Chamber of Commerce and Industry Digest, October 1998.

Eades, J. 1987. Migrant Workers and the Social Order. London: Tavistock Publications.

Esack, F. 1988. Three Islamic Strands in the South African Struggle for Justice. Third World Quarterly No 10.

Esack, F. 1992. Islam in Southern Africa: A Reply to Nkrumah. Review of African Political Economy 53:75-78.

Fassin, D. 2001. The Biopolitics of Otherness: Undocumented Foreigners and Racial Discrimination in French Public Debate. Anthropological Today 17,1:3-7.

Fassin, D. 2011. Policing Borders, Producing Boundaries: The Governmentality of Immigration in Dark Times. Annual Review of Anthropology 40: 213-226.

Ferguson, J. 2005. Seeing like an Oil Company: Space, Security and Global Capital in Neoliberal Africa. American Anthropologist 17,4:551-69.

Ferguson, J. 2006. Global Shadows: African in the Neoliberal World Order. Durham, North Carolina: Duke University Press.

Frank, A.G. 1981. Crisis in the Third World. Teaneck: Holmes and Meier Publishers.

Garnett, J. \& A. Harris 2013. Rescripting Religion in the City: Migration and Religious Identity in the Modern Metropolis. Burlington: Ashgate, Aldershot.

Germain, E. 2007. L'Afrique du sud Musulmane: Histoire des relations entre Indiens et Malais du Cap, Karthala. Johannesburg: IFAS and Paris.

Guyer, J. 2004. Marginal Gains: Monetary Matters in Atlantic Africa. Chicago: University of Chicago Press.

Hagan, J. \& H.R. Ebaugh 2003. Calling upon the Sacred: Migrants' Use of Religion in the Migration Process. International Migration Review 37,4.

Hansen, T.B \& C. Jeannerat \& S. Sodouni 2009. Introduction: Portable Spirits and Itinerant People: Religion and Migration in South Africa in Comparative Perspective. African Studies 68,2:187-196.

Harris, A., N. Ahmed, J. Garnett, B. Gidley \& M. Keith 2016. Shifting Markers of Identity in East London's Diasporic Religious Spaces. Ethnic and Racial Studies 39, 2: 223-242. DOI: 10.1080/01419870.2016.1105993. Hassim, S., E. Worby \& T. Kupe (eds.): Go Home or Die Here: Violence, Xenophobia and the Reinvention of Difference in South Africa. Johannesburg: University of Witwatersrand Press. 
Jinnah, Z. 2015. Chapter 4. Rational Routes? Understanding Somali Migration to South Africa. In Van der Velde, M. \& T. van Naerssen (eds.): Mobility and Migration Choices. Burlington: Ashgate.

Jinnah, Z. 2010. Making Home in a Hostile Land: Understanding Somali Identity, Integration, Livelihood and Risks in Johannesburg. Journal of Sociology and Social Anthropology 1,1-2: 91-99.

Jinnah Z. 2013. New Households, New Rules? Examining the Impact of Migration on Somali Family Life in Johannesburg. QScience Proceedings

2013, Family, Migration \& Dignity Special Issue. http://dx.doi.org/10. 5339/qproc.2013.fmd.7.

Kabeer, N. 2000. Citizenship and the Boundaries of Acknowledged Community: Identity, Affiliation and Exclusion. Sussex, England: Institute for Development Studies. (Working Paper No 171.)

Kadima, D. 2001. Motivations for Emigration and the Character of Economic Contributions of Congolese Emigrants in South Africa. In Morris, A. \& A. Bouillon (eds.): African Immigration to South Africa: Francophone Migration of the 1990s. Pretoria: Protea and IFAS.

Kariya, K. 2012. The Murid Order and its 'Doctrine of Work'. Journal of Religion in Africa 42,1: 54-75.

Klaaren, J. 1997. Citizenship in South Africa and the Impact of Human Rights.

Draft paper. Johannesburg: University of Witwatersrand

Klaaren, J. 1999. Post-Apartheid Citizenship in South Africa. Draft paper. Johannesburg: University of Witwatersrand.

Landau, L. (ed.) 2012. Exorcising the Demons Within: Xenophobia, Violence and Statecraft in Contemporary South Africa. United Nations University Press.

Landau, L. 2014. Religion and the Foundation of Urban Difference: Belief,

Transcendence and Transgression in South Africa and Johannesburg. Global Networks 14,3: 291-305.

Launay, R. 1992. Beyond the Stream: Islam and Society in a West African Town. University of California Press.

Manby, B. 1997. The Human Rights of Undocumented Migrants, Asylum Seekers and Refugees in South Africa. South African Migration Project. Makhulu, A., B.A. Buggenhagen \& M.S. Jackson (eds,) 2010. Hard Work, Hard Times: Global Volatility and African Subjectivities. University of California Press, ebooks; http:www.scholarship.org/ug/item/246027X0. Matthee, H. 2008. Muslim Identities and Political Strategies: A Case Study of 
Muslims in the Greater Cape Town Area of South Africa, 1994-2000. Kassel: Kassel University Press.

Mbembe, A. 1992. The Banality of Power and the Aesthetic of Vulgarity in the Post-Colony. Public Culture 4,2.

Mbembe, A. 2001. On the Post Colony. University of California Press.

McIntosh, J. 2009. The Edge of Islam: Power, Personhood and Ethnoreligious

Boundaries on the Kenya Coast. Durham: Duke University Press.

Misago, J.P., L.B. Landau \& T. Monson 2009. Towards Tolerance, Law, and

Dignity: Addressing Violence against Foreign Nationals in South Africa.

Johannesburg: International Organization for Migration (IOM).

Monson, T., L.B. Landau, J-P. Misago \& T. Polzer 2010. May 2008: Violence Against Foreign Nationals in South Africa: Understanding Causes and Evaluating Responses. Johannesburg: Consortium of Refugees and Migrants in South Africa (CoRMSA).

Morris, A. 2001. Our Fellow Africans Make our Lives Hell: The Lives of Congolese and Nigerians Living in Johannesburg. In Morris, A. \& A. Bouillon (eds.): African Immigration to South Africa: Francophone Migration of the 1990s. Pretoria: Protea and IFAS.

Moser, C. 1996. Confronting Crisis: A Comparative Study of Household Responses to Poverty and Vulnerability in Four Poor Urban Communities. World Bank.

Naidoo, L. 2002. City Welcomes StreetNet International. Address by eThekweni Municipality Deputy Mayor Logie Naidoo. StreetNet Launch, November 12, 2002.

Orkin, M. 2002. HSRC Press Release: Estimations of 'Illegal Immigrants'. 25 April 2002, Pretoria: HSRC Press.

Peberdy, S. \& J. Crush n.d. Criminal Tendencies: Immigrants and Illegality in South Africa. Migration Policy Brief No. 10, South African Migration Project.

Peberdy, S. \& J. Crush 1998. Rooted in Racism: The Origins of the Aliens Control Act. In Peberdy, S. \& J. Crush (eds.): Beyond Control: Immigration and Human Rights in a Democratic South Africa. Johannesburg: Institute for Democratic Alternatives in South Africa and Queen's University.

Peberdy, S. \& J. Crush 1998. Trading Places: Cross Border Traders and the

South African Informal Sector. Southern African Migration Project.

Polzer, T. 2008. Negotiating Rights: The Politics of Local Integration. 
Johannesburg: Forced Migration Studies, University of Witwatersrand. Portes, A. \& J. Walton 1981. Labor, Class and the International System. New York: Academic Press.

Portes, A. 1997. Globalization from Below: The Rise of Transnational Communities. Princton: University of Princeton. (Working Paper, WPTC98-01.)

Reitzes, M. 1997. Strangers Truer than Fiction: The Social and Economic Impact of Migrants on the Johannesburg Inner City. Johannesburg: Centre for Policy Studies. (Research Report No 60.)

Reitzes, M. 1998. Temporary Necessities: The Socio-economic Impact of Cross-border Migrants in Gauteng and North West - A Sectoral Study. Johannesburg: Centre for Policy Studies.

Reitzes, M. 1997. The Migrant Challenge to Realpolitik: Towards a Human Rights-based Approach to Immigration Policy in South and Southern Africa. Johannesburg: Foundation for Global Dialogue. (Occasional Paper No 7.)

Reitzes, M. 1998a. Immigration and Human Rights in South Africa. In Crush, J. (ed.): Beyond Control: Immigration and Human Rights in a Democratic South Africa. Johannesburg: Institute for Democratic Alternatives in South Africa and Queen's University.

Reitzes, M. 1998b. Temporary Necessities: The Socio-Economic Impact of Cross-Border Migrants in Gauteng and North-West - A Sectoral Study. Johannesburg: Centre for Policy Studies.

Rogerson, C.M. 1997. International Migration, Immigrant Entrepreneurs and South African Small Enterprise Economy. Johannesburg: South African Migration Project and Institute for Democratic Alternatives.

Rogerson, C.M. \& D.M. Hart 1989 The Struggle for the Streets: Deregulation and Hawking in South Africa's Major Urban Area. Social Dynamic 15,1: $29-45$.

Sadouni, S. 2014. Playing Global: The Religious Adaptations of Indian and Somali Muslims to Racial Hierarchies and Discrimination in South Africa. Global Networks 14,3: 283-400.

Simone, A. 2001. African Migration and the Remaking of Inner City Johannesburg. In Morris, A. \& A. Bouillon (eds.): African Immigration to South Africa: Francophone Migrants of the 1990s. Pretoria: Protea Book House.

Simone, A. 2004. People as Infrastructure: Intersecting Fragments in Johannes- 
burg. Public Culture 16,1: 407-429.

Soares, B.F. 2004. An African Muslim Saint and his Followers in France. Journal of Ethnic and Migration Studies 30,5: 913-927.

Soares, B. 2007. Rethinking Islam and Muslim Societies. Africa Affairs 106, 423:319-326.

Stiamen, E. \& J. Guyer 1995. Money Matters: Instability, Values and Social Payments in the Modern History of West Africa. New Hampshire: James Currey.

Stiansen, E. \& J. Guyer (eds.) 1999. Credit, Currencies and Culture: African

Financial Institutions in Historical Perspective. Uppsala: Nordiska Afrika institutet.

Stoller, P. 1996. Spaces, Places and Fields: The Politics of West African Trading in New York's Informal Economy. American Anthropologist 98, 4: 776-788.

Stoller, P. 2001. City Life: West African Communities in New York City. Journal of Contemporary Ethnography 30,6: 651-77.

Tayoob, A.K. 1995. Islamic Resurgence in South Africa: The Muslim Youth Movement. Cape Town: University of Cape Town Press.

Tayoob, A.K. 1999. Islam in South Africa: Mosques, Imams and Sermons.

Gainsville: University Press of Florida.

Tayoob, A.K. \& W. Weisse (eds.) 1999. Religion and Politics in South Africa:

From Apartheid to Democracy. New York: Waxman Publishing.

Tlou, J. 2007. Challenges Facing Forced Migrants in Johannesburg and the Non-governmental Response. In Landau, L.B. (ed.): Forced Migration in the New Johannesburg: Towards a Local Government Response. Johannesburg: University of Witwatersrand, Forced Migration Programme.

Vawda, S. 1994. The Emergence of Islam in an African Township. The Journal of Islamic Social Sciences 11,4: 532-47.

Vawda, S. 2000. Foreign Migrants, Governance and Local Development Strategies: A Case Study of International Migrants in Durban. In Skalnik, P. (ed.): Sociocultural Anthropology at the Turn of the Century: Voices from the Periphery. Prague: Set Out.

Vawda, S. 2009. Migration, Livelihoods and Islam: Transnational Muslims Malawians in Durban, South Africa. South African Historical Journal 61,1 .

Von Schimdt, V.H. 2004. Multiple Modernities or Varieties of Modernities. 
Singapore: Department of Sociology, University of Singapore. (Paper No. 149.)

Walters, W. 2015. Reflections on Migration and Governmentality. Movements: Journal für kritische Migrations-und Grenzregimeforschung 1,1. Available at: http://movementsjournal.org/ issues/01.grenzregime/ 04.waltersmigration.governmentality.html.

Shahid Vawda

Department of Anthropology School of Social Sciences University of Witwatersrand shahid.vawda@gmail.com shahid.vawda@wits.ac.za 